\title{
THE PROCESS TO ESTIMATE ECONOMICAL BENEFITS OF SIX SIGMA PROJECTS
}

\author{
DOI: 10.12776/QIP.V17I1.148
}

\author{
JAN KOSINA
}

\section{INTRODUCTION}

Today, companies and industries are under increasing pressure to reduce the costs while the business performance has to improve. The objective related to the business improvement is for the top management obvious: maximization of shareholder value through increased profits.

The activities to assure quality in a company can be grouped in three processes: quality planning, quality control and quality improvement (Juran \& De Feo, 2010). Quality improvement activities does not enhance the quality level only but leads to the costs optimization, improvement of market share or a pricing effect. These outcomes have positive effect on the company profit. From another production - perspective long-term performance of a manufacturing company depends on quality and efficiency of the production processes therefore the improvement in this area has the positive effect on the profit as well. In addition a quality improvement programm leads to the creation of the product that customer values so the customer satisfaction increases as another important longterm success indicator for a company.

\section{THE HYPOTHESES}

Quality improvement activities are executed in projects and this systematic project base distinguishes quality improvement from quality control, which is based on the reactive approach. Several quality improvement strategies, which are statisticaly based have been developed, in order to guide quality professionals to perform improvement projects. The most frequently used are the Six Sigma methodology, the Shainin System and Taguchi's methods.

The selection of the quality improvement projects in the rapidly developing industries such as automotive or electronics suggests evaluation of effort and resources allocated to the project in order to deliver maximum benefits to the company. Project selection process have became crucial as the effectiveness of 
the quality improvement programs is one of the key factors for the fulfilment of the business objectives and development of the employees.

The way the Six Sigma methodology is used has changed in last few years. The influence of the economic crisis led to the situation the improvement programs are evaluated more strongly by economical criteria. In the past the Six Sigma programs were not defined based on the economics aspects primarily but rather on a confidence or a trust the quality improvement can bring a positive effect. Six Sigma was taken as a quality initiative that does target the cost reduction secondarily. It means the quality improvement could save money by eliminating of the defective products, rework or returned products but this was taken as a byproduct of the project.

In this paper we will seek for the estimation of benefits coming out of an improvement project especially focusing on Six Sigma projects.

\section{TEST OF HYPOTHESES}

\subsection{Six Sigma methodology}

Six Sigma is a robust continuous improvement strategy that rely on statistical methods. But Six Sigma is more than a set of tools. Six Sigma is the strategic and systematic application of the tools on a project in order to reach significant and long-term improvement. In general Six Sigma methodology solves the process or business problem by reduction of the variation (Nave, 2002). Six Sigma methodology provides a structured data-driven approach based on statistical methods that companies use to measure their performance both before and after an improvement projects. No changes are made until the current process is completely understood, documented and measured. The revised process is measured and verified after the improvement action is finished. Apart from that we have to consider Six Sigma as the approach strongly focused on the customer needs. Basically the DMAIC process translates customer requirements into operational terms and defines the processes critical to quality which must be completed to meet customer needs (Juran \& De Feo, 2010). Six Sigma methodology consists of five steps known as DMAIC process (Table 1). 
Table 1 - DMAIC structure of Six Sigma strategy

\begin{tabular}{|c|c|}
\hline Define & $\begin{array}{l}\text { - Define the customer and their 'Critical To Quality' characteristics (VOC) } \\
\text { - Define the business processes that are involved (VOB) } \\
\text { - Create a process map } \\
\text { - Decide on the metrics } \\
\text { - Form a project team and develop a project charter } \\
\text { - Evaluate the financial savings of the six sigma project }\end{array}$ \\
\hline Measure & - Monitor the existing process by acquiring data from the process \\
\hline Analyze & $\begin{array}{l}\text { - Data analysis } \\
\text { - Gap analysis between current and required performance } \\
\text { - Indentify the sources of variation } \\
\text { - Decide on the processes to be improved }\end{array}$ \\
\hline Improve & $\begin{array}{l}\text { - Propose solutions } \\
\text { - Perform pilot studies, design of experiments etc. to evaluate proposed } \\
\text { solution } \\
\text { - Create an implementation plan } \\
\text { - Implement changes }\end{array}$ \\
\hline Control & $\begin{array}{l}\text { - Implement controls to ensure improvement is reached and stable } \\
\text { - Develop procedures and train the staff } \\
\text { - Update control plan, FMEA and related quality documentation } \\
\text { - Evaluate the financial savings of the six sigma project }\end{array}$ \\
\hline
\end{tabular}

\subsection{Six Sigma and business improvement}

To select a beneficial improvement project a company has to to work with two main inputs: Voice of Customer (VOC) and Voice of Business (VOB). VOC is the most powerful input. Why VOC is so strong? The reason is obvious: the customer is the reason to run the business. Significant portion of the Six Sigma projects is initiated based on customer request or, in the worst case, on customer complaint. Voice of Business (VOB) is an inner voice of the company. Perhaps it is not as strong voice as VOC but many improvement actions and activities have arisen from the identification of the internal needs and gaps within the processes.

These two voices are linked together through process output that has to comply with requirements specified internally by business needs and externally by customer requirements. Properly selected Six Sigma project will be in line with customer expectation and business priorities if the VOC and VOB is reflected. This would guarantee the validity and the priority of the project which can be recognized by management.

A quality improvement activity brings two main effects: improvement of the product characteristics and failure reduction. A real quality improvement should end up by the economical benefit represented increased profit at the end (see Figure 1). 
The improvement of the production quality and product quality leads to the high production efficiency, prevention of the scrap and decreasing of the process variance. The costs of poor quality are minimized and thereby the production costs are lower so unit costs are decreased as well. Higher internal quality contributes to low level of external failures. It causes the external effect as customer satisfaction increases due to low defect rate of the product in the market.

The better quality can have a positive effect on the pricing as customer will start to distinguish between low and high quality product as shown on Fgure 2 (Freiesleben, 2004).

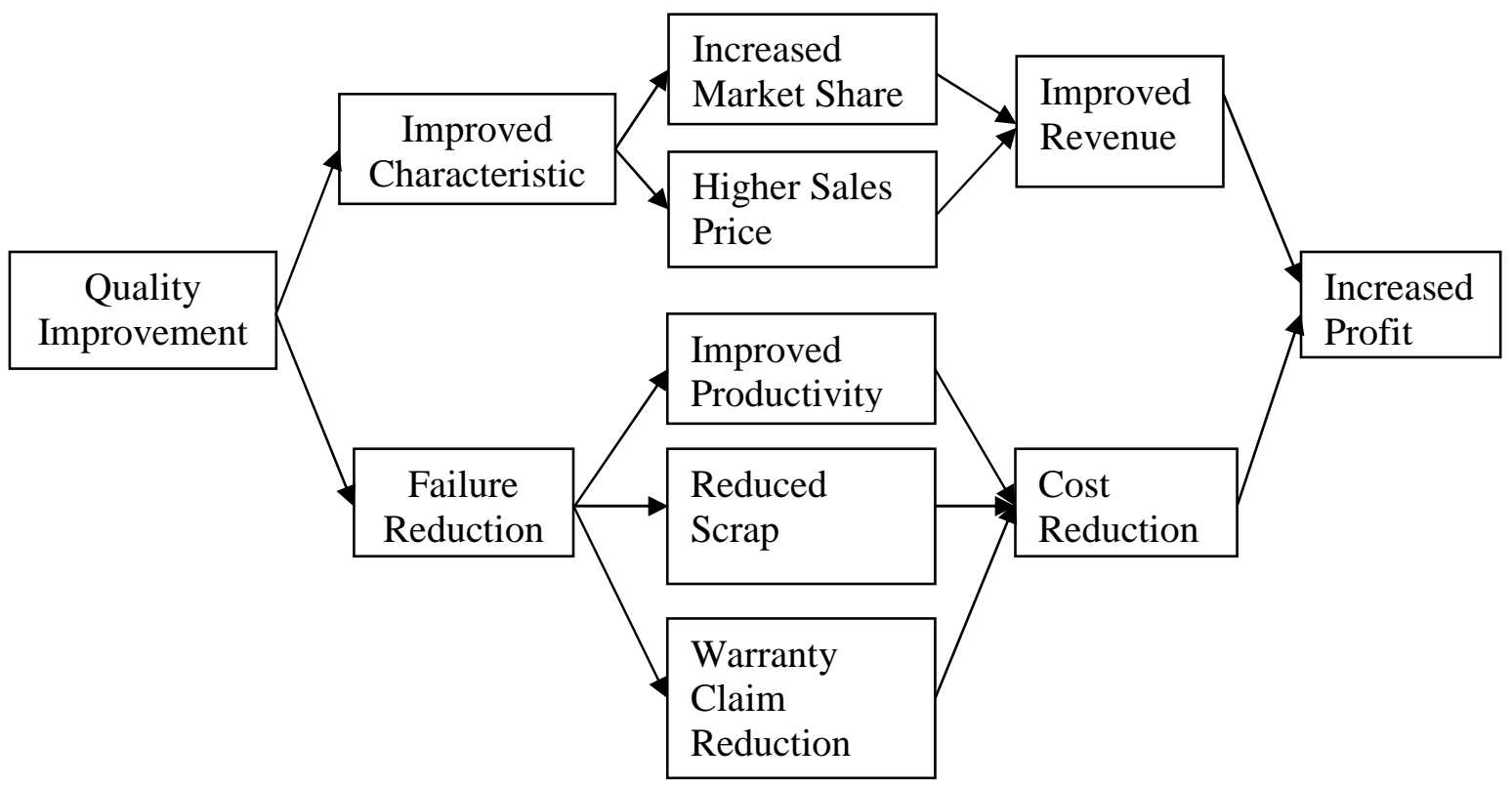

Figure 1 -Economics of a quality improvement project

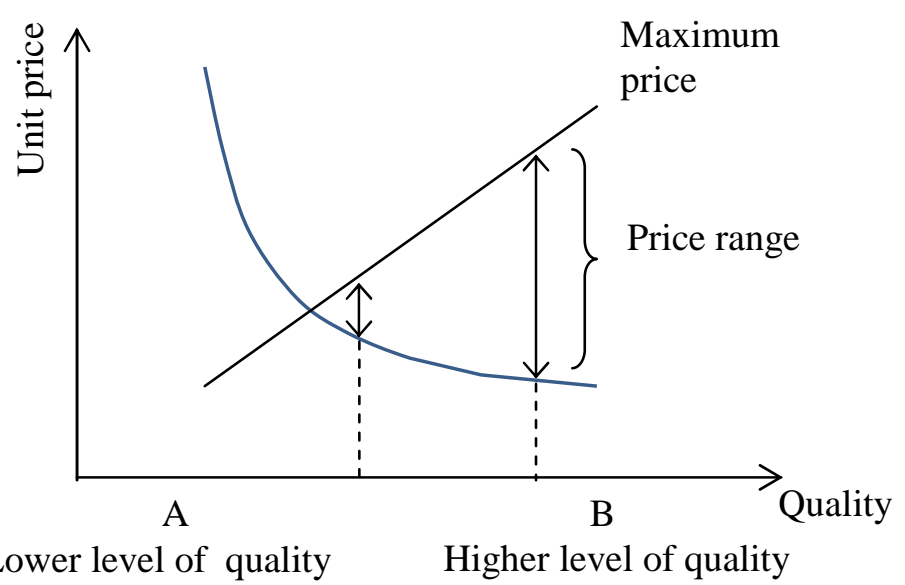

Figure 2 - The effect of pricing (Freiesleben, 2004) 
Quality improvement is linked to quality costs. The structure of the quality costs can be explained by traditional quality costs model, (PAF model, PreventionAppraisal-Failure model) which defines these costs consisting of four costs categories: internal failure costs, external failure costs, appraisal costs and prevention costs. (Nenadal, 2004). Total quality costs are the sum of the costs of poor quality and the costs of achieving good quality then (see Figure 3).

The analysis of the costs of poor quality itself does not create a good base for the financial evaluation of the quality improvement project. The reduction of the quality costs will minimize the production costs but this analysis will not demonstrate the contribution to the profit increase (Miller \& Morris, 2000). The missing link between benefits and costs of poor quality is revenue (Figure 4). As shown in Figure 1 revenue can be increased if market share is increased and/or the price is heighten. In Figure 4 revenue is shown as increasing function of quality. Net profit of the company is the difference between total revenue and total quality costs. Point $\mathrm{Q}_{1}$ represents the quality level with total costs of quality being minimized. Profit maximization is reached in the point $\mathrm{Q}_{2}$. Further improvement of the quality between $\mathrm{Q}_{1}$ and $\mathrm{Q}_{2}$ causes the slight increase of the total quality costs however the slope of the total revenue line is steeper therefore the additional profit is created The lower graph illustrates the same situation displaying marginal values of the revenue and costs in relation to quality. Marginal lines represents the slope of the absolute characteristics: marginal costs shows the slope of the total costs line and marginal revenue is equal to the slope of the total revenue line. Revenue exceeds marginal costs in point $\mathrm{Q}_{1}$ so at minimum costs of quality.

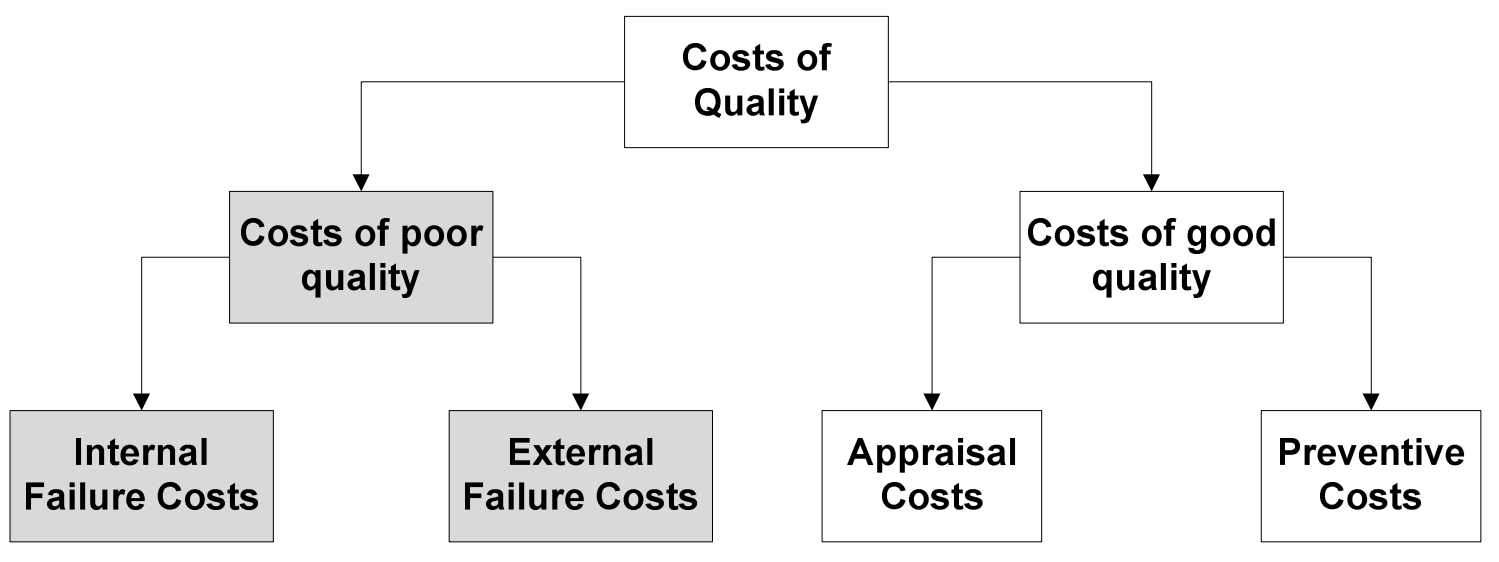

Figure 3 - Costs of quality structure (PAF model)

\subsection{Evaluation of Six Sigma projects by savings}

The assessment ot the project benefits using revenue or net profit is not an easy part especially for green belts. In reality the financial impact of the individual Six Sigma project is evaluated through savings. The project charter of each Six 
Sigma project should show the overview of the expected savings in the Define phase already. Two groups of Six Sigma savings are defined: hard and soft. Hard savings influence the year-to-year financial results, reduce spendings and budget variances. The hard savings are categorized as cost reduction and revenue enhancement. Soft savings improve the cash flow, impact future capital budgeting and they may influence the capital spendings. There are three categories of the soft savings: cash flow improvement, cost and capital avoidance (Snee \& Rodebaugh, 2002).

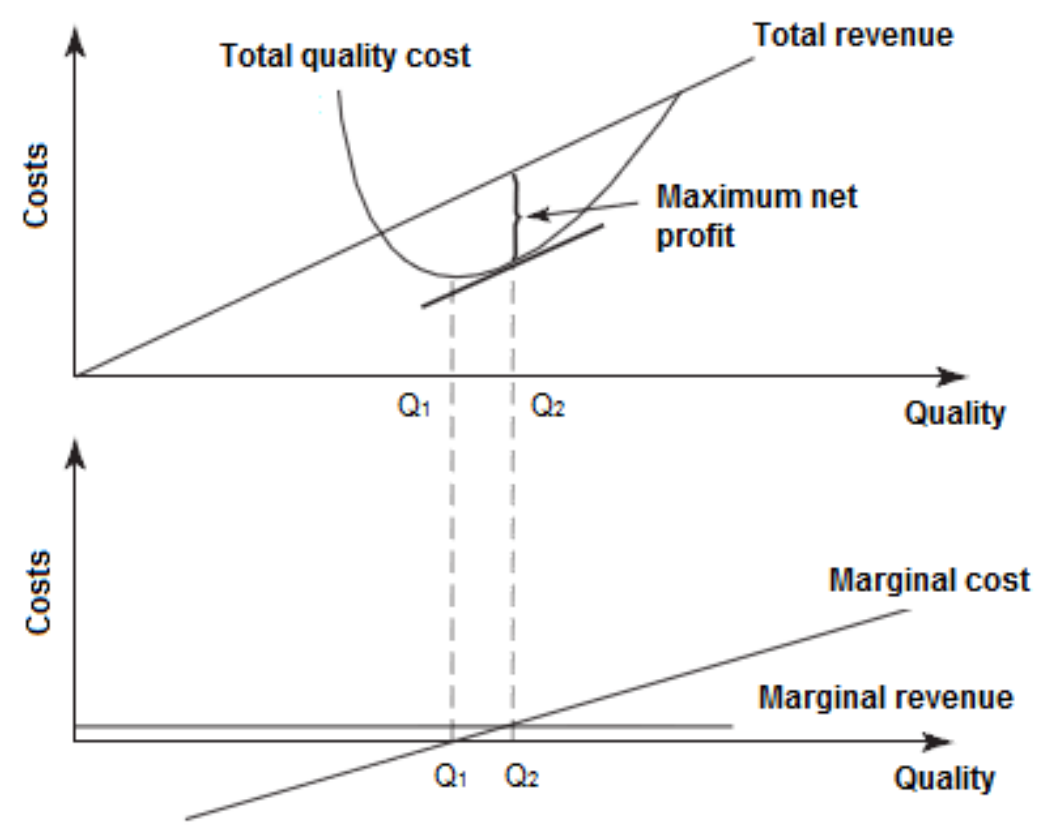

Figure 4-Quality costs versus revenue

Explanation: $Q_{1}$ - the quality level with total costs of quality being minimized; $Q_{2}-$ profit maximization

Although savings are well defined from economical point to assess the project savings is the most difficult point for green belts and black belts and it could become blocking point to start a project. Why is this point so painful? Most of the green belts and black belts are employees with technical background but with low knowledge regarding business economy. If we look at the agenda of a Six Sigma green belt or black belt course we will find sporadic information about business economics related to the Six Sigma methodology. Not sufficient economical knowledge leads to the fact the green belts and black belts are trying to link their Six Sigma project to a most obvious saving. The simplification does not allow proper project rating as one project influences several categories of savings usually. The situation is more complicated with soft savings which are difficult to recognize and quantify. 
Table 2 - Savings categories

\begin{tabular}{|l|l|l|l|}
\hline $\begin{array}{l}\text { Savings } \\
\text { category }\end{array}$ & Savings type & Improvement area & Indicator \\
\hline Hard & $\begin{array}{l}\text { Revenue } \\
\text { enhancement }\end{array}$ & Capacity increase & Production volume \\
\cline { 2 - 4 } & Cost reduction & Quality improvement & ppm, cp/cpk \\
\cline { 2 - 4 } & Cost reduction & $\begin{array}{l}\text { Incoming material } \\
\text { price and quality }\end{array}$ & Reduction of input costs \\
\cline { 2 - 4 } & Cost reduction & Process efficiency & Efficiency, cost reduction \\
\hline Soft & $\begin{array}{l}\text { Cash flow } \\
\text { improvement }\end{array}$ & Inventory reduction & Inventory level reduction \\
\cline { 2 - 4 } & Cost avoidance & Testing & Testing time, testing frequency \\
\cline { 2 - 4 } & $\begin{array}{l}\text { Capital } \\
\text { avoidance }\end{array}$ & $\begin{array}{l}\text { Production flow } \\
\text { optimization }\end{array}$ & Capital investment budget \\
\hline
\end{tabular}

\subsection{Financial based concepts to evaluate benefits of Six Sigma projects}

The most popular concept (and to be honest the one which is usually explained on the green belt/black belt course) is known as hidden factory. This concept is based on the elimination of so called hidden factory costs. Example: we have to produce $\mathrm{x}$ good products and our actual defect rate is q. To fulfill customer needs for delivered volume (v) we have to produce volume

$$
v=\frac{x}{1-q}
$$

If we consider $\mathrm{c}$ as variable cost per unit then related variable costs

$$
C=c .(v-x)
$$

are indirect costs of poor quality caused by overproduction (Bisgaard \& Freiesleben, 2000). The calculation of the cost savings related to Six Sigma project could be simplified using this concept as hidden factory costs are equal to the savings. This simplified way of calculation ignores the investment to the improvement of the process. The improvement action has long-term effect while spending related to improvement could be taken as a one-time investment. From accounting point of costs related to investment will be written off for certain time. This allows us to evaluate the benefit of Six Sigma program by return of investment (ROI) calculation.

Unadjusted return of investment can be expressed by formula (Bisgaard \& Freiesleben, 2000):

$$
R O I=\frac{100 .(\text { Opertaing advatage }- \text { Amortisation })}{\text { Investment }}
$$


This calculation does not include the interest rate in to judgement.

The expectation related to the usage of the ROI as the criteria for the evaluation of the benefit of Six Sigma program is one time investment. This condition comes true for green belt projects which take approximately three to six months to complete. The situation differentiates from ongoing long-term improvement activities. Leading companies implemented different approach to improve the quality of their product based on the continuous, systematic innovation strategy. Such strategy can contain process innovation, product innovation as well as radical and incremental innovation (Bisgaard \& De Mast, 2006). The innovation strategy is executed by the structured improvement programs where the Six Sigma is used as an engine to run the improvement process. An advanced innovation programme starts in the design phase already where the Design for Six Sigma (DFSS) approach can be used to set up the appropriate quality level and economical effectiveness of the product and process prior production phase. These improvement activities have to be evaluated from economical point as long-term projects that have different cash flow developing over several years. The net present value (NPV) could be suitable characteristic to evaluate such long-term activity. The expected future incomes and outcomes are converted to current value using an estimated rate taking in account the "time value of money". The NPV can be expressed by the formula:

$$
N P V=\sum_{n=0}^{t} \frac{\text { investment value }}{(1+\text { rate })^{2}}
$$

Investment value is the sum of the costs and revenues related to investment realization, $\mathrm{n}$ represents individual years of the investment utilization, $\mathrm{t}$ means total investment utilization and rate is related to the alternative valorization which reflects amount of interests (Kral, 2010).. Even the formula looks simple I would strongly recommend to ask financial department for the support in case of the evaluation of NPV.

There are further methods the financial impact evaluation of six sigma projects which are even more based on the accounting approach i.e. EVA method (Mader, 2009).

\subsection{Process for continuous evaluation of the project benefits during project life time}

The financial benefits are the key aspects of the Six Sigma projects which have to be taken in consideration before a project is launched. Unfortunately there is no simple way how to calculate the financial benefit coming out of the project. The idea the cost savings being assessed by green belts or black belts themselves does not bring a value usually. The only effective solution is to involve finance department in the evaluation of the Six Sigma project from an early phase. This is nothing revolutionary new: a Six Sigma project has to be simply traced any 
evaluated as any other project in the company. The financial metrics are just implemented as the key performance indicators of the project. The most effective way to evaluate benefits of Six Sigma projects is to create continuous project evaluation process to maintain the tracking of project development closely. At the beginning of the project the key metrics are defined in the project charter which has been created as soon as the project idea is generated. Well-defined project charter outlines the scope of a project, financial targets, anticipated benefits and. In the initial phase it is important to generate the metrics by green belt and black belt. The financial metrics are reviewed with finance department taking in account product life cycle phase, complexity and expected duration of the project, expected investments, hard and soft savings. The project pre-agreed with finance department is submitted to Six Sigma steering committee to decide about release of project for execution. The status of the project is reviewed after each milestone of the project (Define, Measure, Analyze, Improve, Control milestone at least) including the financial indicators. The project status at the point of milestone is the key decision point (but not only one) to differentiate the projects with high benefit potential from projects with low expectation. The final evaluation of the Six Sigma project benefits is done six months after the project closure. The complete flow describing the process of continuous evaluation of the Six Sigma benefits is shown by Figure 5 . 


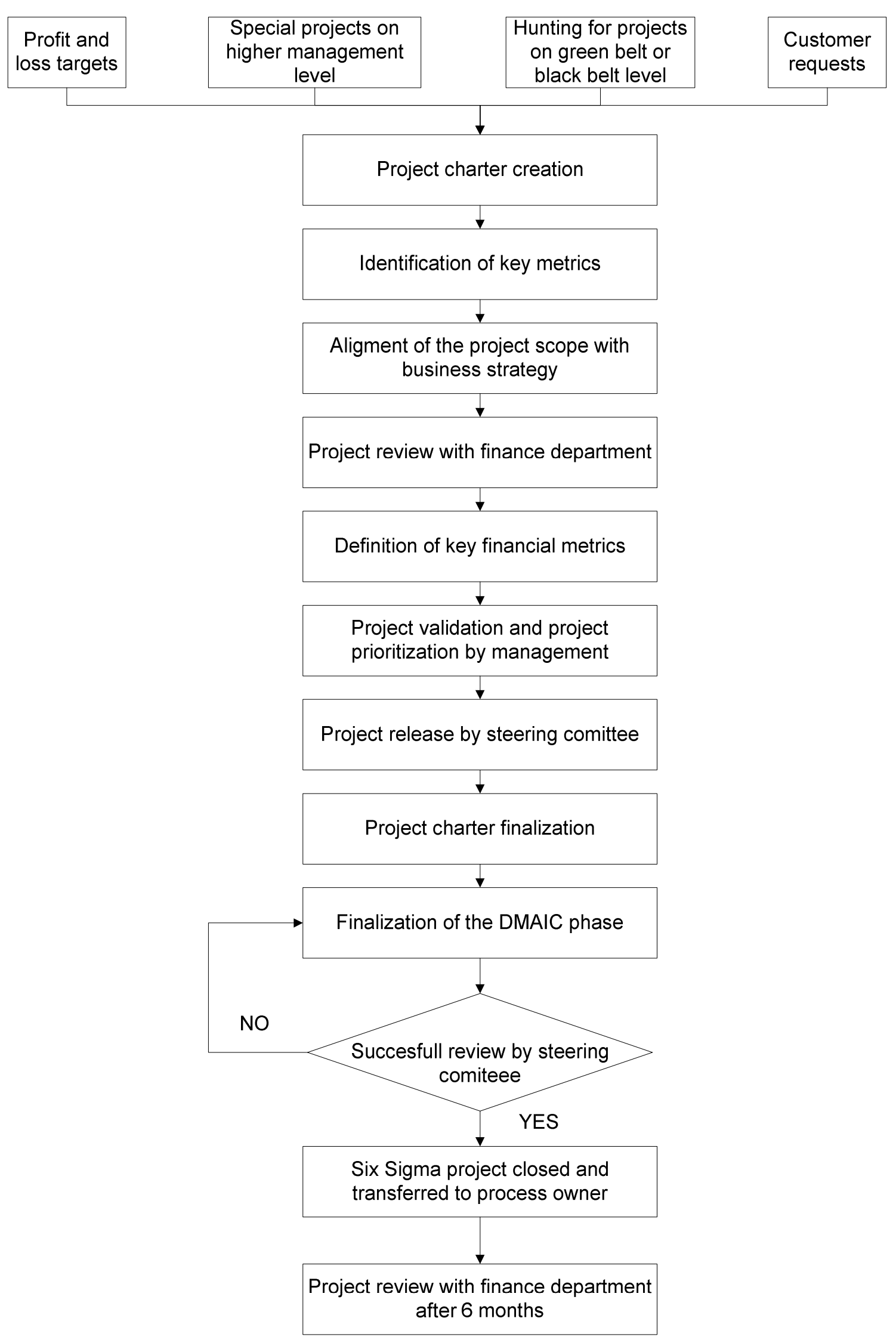

Figure 5 - Continuous evaluation of the six sigma project benefits 


\section{CONCLUSION}

Six Sigma is not just another project management initiative or process improvement program. It is more than that because it is a robust continuous improvement strategy which affects the bottom-line of the company. The market environment forces companies to utilize quality improvement methodologies and innovation programs as the key processes which helps to create the company profit. An improvement or innovation project has to be properly assessed during the regular milestone review. The milestones are in case of Six Sigma related to DMAIC steps usually. The financial criteria plays the important role in the project assessment to distinguish the potencially beneficial projects. The projects which are not on the way to bring the benefit have to be analysed properly and the final decission has to be made whether to get project back on track or to close the project in order to avoid the resources are wasted. Financial department plays the irreplaceable role in this process and it is necessary to involve the financial experts from the beginning into the project. The introduction of a multidisciplinary approach requires the establishement of the process to evaluate the project development in the structured way as outlined in this paper.

\section{REFERENCES}

Bisgaard S., De Mast J., 2006. After Six Sigma - What's Next?, Quality Progress, March 2206, pp. 30-36.

Bisgaard, S., Freiesleben, J., 2000. Economics of Six Sigma Programs, Quality Engineering", Vol. 13, Issue 2, pp. 325 - 331.

Freiesleben, J., 2004. How Better Quality Affects Pricing, Quality Progress, February 2004, pp. 48-52.

Juran J. M., De Feo, J. A., 2010. Juran's Quality Handbook, Sixth edition, New York: McGraw-Hill Professional, 1136 p., ISBN: 978-0-07-162973-7.

Král, B., 2010. Manažerské účetnictví. Praha: Management Press, 660 p., ISBN: 978-80-7261-217-8.

Mader, D. P., 2009. 3.4 per million. The Right Decission, Quality Progress, November 2009, pp. 50-51.

Miller, J. R., Morris, J. S., 2000. Is Quality Free or Profitable?, Quality Progress, January 2000, pp. 50-53.

Nave, D., 2002. How To Compare Six Sigma, Lean and the Theory of Constraints, Quality Progress, March 2002, pp. 73-78.

Nenadál J., 2004. Měrení v systémech managementu jakosti. Praha: Management Press, 335 p., ISBN:80-7261-110-0.

Snee, R. D., Rodebaugh, W. F., 2002. The Project Selection Process, Quality Progress, September 2002, pp.78-80. 


\section{ABOUT THE AUTHOR}

Ing. Jan Kosina - Continental Automotive Czech Republic, external PhD. student VŠB-Technical University of Ostrava, Faculty of Metallurgy and Materials Engineering, Department of Quality Management, Czech Republic, e-mail: jan.kosina@continental-corporation.com. 